\title{
Investigating Kindergarten Parents' Selection of After-School Art Education Settings in Taiwan
}

\author{
Ching-Yuan Hsiao ${ }^{1}$ \& Ting-Yin $\mathrm{Kuo}^{2}$ \\ ${ }^{1}$ Department of Early Childhood Education, National University of Tainan, Tainan, Taiwan \\ ${ }^{2}$ Kaohsiung Municipal Cianjin Kindergarten, Kaohsiung, Taiwan \\ Correspondence: Ching-Yuan Hsiao, Department of Early Childhood Education, National University of Tainan. \\ Address: 33, Sec. 2, Shu-Lin St., Tainan 700, Taiwan. Tel: 886-929-040-353. E-mail: cyh111@mail.nutn.edu.tw
}

\author{
Received: March 25, $2012 \quad$ Accepted: November 18, $2013 \quad$ Online Published: November 21, 2013 \\ doi:10.5539/jel.v2n4p208 URL: http://dx.doi.org/10.5539/jel.v2n4p208
}

\begin{abstract}
The research purpose was to investigate kindergarten parents' selection of after-school art education settings in Taiwan. A review of the literature and interviews with parents were conducted to identify several possible factors that would impact on parents' selection of after-school art education settings for their children. Then, the researcher self-compiled a survey and distributed 550 copies to parents and 515 copies were obtained. The effective return rate was $93.6 \%$. The findings were as follows: 1 . The majority of parents believed children can attend after-school art education settings at the age of four years, and parents also believed that art specialists have a great impact on children's drawings. 2. Type of kindergarten attended by children (public or private), mother's age, mother's occupation, and education level of mother and father have significant effects on decision making regarding the selection of after-school art education settings for their children. 3 . The effects on learning: More than $85 \%$ of the parents believed that their children have achieved their expectation, which was to enrich creativity, patience, and attention. And, over $80 \%$ of the children discussed what they had learned with their parents. 4. The most popular way to teach is to combine teacher-directed and student-directed methods. 5. The most frequently used art materials are markers and crayons in after-school art education settings.
\end{abstract}

Keywords: after-school art education settings, factors, parents' choice, kindergarten children, art specialists

\section{Introduction}

At early developmental stages, children frequently cannot use words to fully express their ideas so they draw images that enable them to better express their thoughts and communicate with adults. Moreover, children also express their feelings and emotions during the creation of artwork. Therefore, the learning environment and teaching quality are very important factors in enhancing children's artistic development. Most children love to make drawings. Young children present their inner world, express their emotions, and evoke joyful feelings when they make drawings; Lowenfeld (1970) stated that children's artwork reflects their creative, cognitive, and emotional development.

I found this to be true when I worked with kindergarten children on art activities in Taiwan several years. The children enjoyed it so much that their parents would ask me, "do you offer after-school art education settings somewhere?" The kindergarten homeroom teachers also told me that parents were eager to learn more about choosing an appropriate after-school art education setting for their children. Even though the Taiwanese kindergarten curricula already includes art subject, parents still believe that their children need supplemental art classes. Engagement in art classes is one of the areas believed by Taiwanese parents to indicate a well-rounded education. The parents' goal is to ensure that their children learn well in all subjects and get good results in competitions. Hong (2008) claimed, however, that this view indicates an incorrect perception by parents - children cannot excel in everything.

Parents should understand that the key factors in learning are motivation and interests. Without these two, participation in after-school art education would be a waste of time and money. Further, it could lead to a conflict between parents and children. Since parents often dominate children's decision-making in their early stages, their beliefs and attitudes are significantly important in selecting after-school art education settings. 
The goal of the study described here was to investigate the factors that affect parents' selection of after-school art education settings. Moreover, I examined the differences between public and private kindergarten parents' perspectives and attitudes toward after-school art education settings. Study results can provide parents with some appropriate notions about choosing after-school art education settings. Furthermore, they may affect the ways in which art education instruction is offered to young children in after-school art education settings. Therefore, the research project outlined here has significant value for both educators and parents of kindergarten-age children.

\subsection{Research Questions}

This study had three research questions and five hypotheses. The first research question had two parts: What is the current situation of kindergarten-aged participants in after-school art education settings in southern Taiwan? What is the difference between public and private kindergarten parents' reports of these kindergartners in these settings? The second research question was: How does the availability of different types of kindergartens influence parents' selection of after-school art education settings? The third research question was: How do differences in parents' backgrounds influence their selection of after-school art education settings? Information on the five hypotheses relates to questions 2 and 3 and may be found in the findings section.

\section{Review of Selected Literature and Research}

\subsection{Children's Art Education}

Stokrocki (2000) stated that children make drawings based on what they think, not what they see. Toku (2001) claimed that children make drawings based on having pleasure rather than what they know. Hanes and Weisman (2003) noted that children's art is influenced by adults. Adults should encourage children to express themselves through drawings, and provide opportunities to draw in a manner that reflects their daily life experiences. Therefore, adults should emphasize the art-making process rather than art products. Lasky and Mukerji (1980) mentioned that although adults do not fully understand the symbols in children's drawings, they still need to provide children with opportunities to make drawings and to construct their own pictorial meanings (Lasky \& Mukerji, 1980; see also Danko-McGhee \& Slutsky, 2003). Hamblen (2003) believed that adults' art concepts facilitate K-12 students' art experience. Danko-McGhee and Slutsky (2003) stated that art-making not only facilitates children's development of art skills but enhances their art learning experience. Moreover, by participating in art activities, children can develop the following abilities: 1) Children can transform their feelings and notions into visual forms; 2) Children can appreciate the beauty of daily objects; 3) Children can realize that artwork represents a culture and a period of history; and 4) Art can be presented in multicultural form and also in mass media. Chen (1998) claimed that a child's drawing behavior was not merely "a mechanical act of image making"- it also presented the process of interaction between the child's mind and prior experiences (p. 7). Hamblen (2003) mentioned that art educators are more focused on the art creation process than artwork. Art education experts also believe that learning art has the following benefits: visual thinking strategies, art creating ability, problem-solving skills, and acceptance of different art concepts.

\subsection{Creativity and Self-Expression}

Based on modern education theory (i.e., Lowenfeld theory), creative growth is the same as perceptual, physical, cognitive, social, and aesthetic growth with regard to the basic elements of children's growth. The art experience is considered to be very helpful to each growth area, and creativity growth is at the top of the list. Art specialists can, through discussion of an art activity, encourage children to recall a good memory, emotion, or life experience; and then ask the children to imagine their future life and draw it. In doing so, teachers cultivate the whole-child (Wilson, 1992). Efland et al. (1996) also believed that many art teachers conduct art activities under the modern theory. For instance, art teachers evaluate children's art ability according to the level of originality/creativity displayed in their art products in the studio. In the modern period, self-expression has become an important philosophy and has influenced many art specialists' teaching methods since 1920 (Liu, 2001).

\subsection{After-School Art Education Settings}

According to Chen (1998), parents send children to after-school art education settings because: 1) parents did not have an opportunity to attend arts classes when they were young, so they wish their children to have a better arts education than they did; 2) parents work full-time, so they send children to after-school art education settings in order not to have to make an alternative after-school arrangement; 3) some after-school art education settings hire art specialists who may train children to win awards in drawing competitions, making them famous in certain settings; and 4) some kindergartens add after-school art education settings to their curricula in order to recruit more students. Fitzhugh (2002) indicated that attending after-school art education settings improves 
youngsters' self-confidence and discipline, respectful relationships with others, development of learning skills, willingness to try new things and take risks, awareness of their own creativity, and ability to learn in many subjects. Bergonzi and Smith (1996) stated that adults' choices and notions vitally influence children's art experiences. Stokrocki (2000) suggested that children's artistic development is influenced by social, economic, peer imitation, and commercial behaviors. This influence is still exhibited in adulthood. Galbraith (1991) found that primary school teachers' artworks exhibited signs of influence from their early art education experiences. Hamblen (2003) claimed that daily life experiences are very important to learning art and artistic development.

Studies have indicated that when parents select after-school art education settings, they consider the following elements (Lee, 2006; Qian, 2005; Young, 2004): 1) teaching and learning effects; 2) arts instructors; and 3) parents' expectations. Each element is described as follows:

1) Teaching and learning effects:

a. Teaching methods: Good teaching methods enrich children's learning motivations.

b. Curricula: Art specialists should design variety curricula that include cognitive, emotional, and techniques aspects. Moreover, they should conduct arts activities that involve playing arts games.

c. Children's development: Art specialists should adopt the Developmentally Appropriate Practices approach when they conduct arts activities.

d. Environment: A good learning environment will enhance children's arts learning. Parents should pay attention to the safety and size of classrooms in after-school art education settings.

2) Arts instructors' effects:

a. Personality: Art specialists should have not only professional art competence but the personal characters needed to facilitate children's needs and be good care-givers.

b. Education background: Parents should be familiar with art specialists' background and expertise before inviting children to attend after-school art education settings.

3) Parents' expectations:

a. For better results: some parents hope their children can create artwork in a realistic manner.

b. Enhance art skills: some parents hope their children will make better drawings than their friends.

c. To cultivate patience: some parents hope children can sit quietly and concentrate on learning.

d. Be familiar with art specialists: some parents prefer having children attend the same after-school art education settings as their arts education friends.

e. Review: Parents would seek friends' or relatives' comments about art specialists before selecting after-school art education settings.

\subsection{Studies of Taiwanese After-School Art Education Settings}

According to the Su (2007) study, 61\% of kindergartens had hired art specialists in Taipei city. Art specialists designed the art curricula by themselves. Kindergarteners attended art talent classes one hour per week, and engaged in art activities in regular classrooms. Art specialists tended to be art studio educators, art-related degree holders, educators with art certificates, and early childhood teachers. Young's (2004) study indicated that primary school parents' motivation for sending children to after-school art education settings is to cultivate children's hobbies and enrich their arts talent. The majority of parents reported having children participate in after-school art education settings right after their daytime coursework Monday to Friday, one day per week. Most mentioned that children's motivation is the key factor in having them attend after-school art education settings. Lin (2006) investigated parents' selection of after-school art education settings for primary school-aged children. She found that parents' highest education degrees earned related to type of after-school art education settings selected. Most questionnaires were answered by mothers who obtained college degrees. Lin (2006) studied the factors affecting parents' choice of talent art courses in public kindergartens in Taipei, and found that: Parents choose talent art courses based on child's age (71.2\%); child's gender (53.1\%); and children's learning motivation, school facilities and environment, school location, art curriculum, and teachers' art ability. Pan (2003) conducted a case study of children's talent art schools and found that: 1) Children's talent art schools are very prosperous in Taiwan as a result of changes in socioeconomic trends (parents are earning more money and having fewer children; 2) parents believe that making it possible for their children to gain art skills will give them a better chance of getting into a good college; 3 ) art talent courses teach art skills and how to play with art 
materials at the same time-providing another kind of leisure activity; and 4) art talent courses supplement formal school education to improve students' art skills. In addition, socioeconomic factors play an important role in artistic development. Chen (2007) investigated household expenditures for primary school students-after-school art education settings ranked second in all such expenditures. Moreover, parents who had attained a higher education degree invested more money in their children's education.

\section{Methods}

A research plan was devised before conducting this study and analyzing the data. The questionnaire was developed and piloted before gathering data from kindergarten parents in early childhood settings to investigate the factors affecting their selection of after-school art education settings. The participants in this study were 550 parents whose children attended after-school art education classes in Taiwan. The quantitative research data were analyzed using descriptive statistics, One-Way Analysis of Variance, and a t-test.

\subsection{Population and Sample}

The purpose of the study was to investigate parents' selection of after-school art education settings in Taiwan. The main study was conducted in southern Taiwan. Using the 2012 Ministry of Education list of kindergartens, the researcher selected the major kindergartens in southern Taiwan for the main study. The directors of kindergartens recommended the key teacher list for southern Taiwan kindergartens because they felt that the key teachers would be helpful in contacting parents whose children had attended after-school art education settings. The researcher contacted key teachers by telephone; all agreed to participate in this study.

\subsection{Data Collection}

The data collection method was quantitative, and the researcher adopted self-compiled questionnaires to gather information on the factors affecting parents' selection of after-school art education settings. The researcher began to collect the questionnaires from the key teachers one week after the teachers received them and within one month had collected all of them. Of the 550 questionnaires distributed, 515 were returned for a $93.6 \%$ return rate. Borg and Gall (1989) stated that the salience of a survey's content can significantly affect the return rate. Fifty-six of the kindergarten parents' responses to the questionnaire were discarded because they had not answered a significant proportion of the items, so that $84.2 \%$ of the questionnaires were used in the statistical analysis.

\subsection{Data Analysis}

Data analysis for the quantitative part of this study was conducted using the IBM SPSS Grad Pack 12.0. For reliability, the researcher used Cronbach's alpha coefficient to determine the internal consistency of the instrument. Reliability was calculated using the data provided by the study respondents. Nunnally stated that Cronbach's alpha in basic research need to have a reliability of about .70 or better $(1978, \mathrm{p}$. 245). The Cronbach's alpha was .85 for the entire study, indicating that the results obtained via the instruments were acceptable.

\section{Results and Analyses of Findings}

4.1 Research Question One: What is the Current Situation of Kindergarten-Aged Participants in After-School Art Education Settings in Southern Taiwan? What Is the Difference between Public and Private Kindergarten Parents' Reports of These Kindergartners in These Settings?

Both public and private kindergarten parents whose children had attended after-school art education settings reported that the majority of art specialists had art-related degrees. In interviews with parents, the common comment was, "Art class should be taught by an art specialist." Su (2007) also found the 61\% of art specialists conducted art activities in both public and private kindergartens in Taipei city. The majority believed that art specialists' personality was the most important factor to parents as they selected from among after-school art education settings. One parent said that she would "choose an art specialist who knew how to inspire children's creative thinking and always consider children's need in after-school art program." Parents reported that art specialists conducted art activities following in part a teacher-oriented method. One parent said, "Art specialists read art stories or played games in the beginning of class, and then she would assign a topic to let children create artworks spontaneously." Parents reported that their children used crayons, markers, and watercolors most frequently in after-school art education settings.

Baghban (1992) stated that children's drawings are more stereotypical than before; contents also reveal less exploration. This is due to the art materials available to them such as crayons and pencils. Baghban recommended that adults provide "messier" art materials, and encourage children to engage in more 
experimental drawings. In this study, more than $65 \%$ of art specialists provided watercolors in after-school art education settings, indicating art specialists' greater willingness to let children explore messy art materials in Taiwan now.

Moreover, they also mentioned the most popular drawing topics are animals, plants, and daily life. The ideal time for attending after-school art program is right after daytime courses. Almost $90 \%$ of parents reported that their children attended after-school art education settings one day per week - an amount of time they perceived as appropriate. Over $60 \%$ of parents stated that they respect their children's decision to no longer attend after-school art education. As one parent mentioned during an interview, "if my child was not interesting in learning art anymore, it would be useless and a waste of time/money to force the child to attend after-school art education settings." More than $85 \%$ of the parents believed that their children had achieved their expectations, which was to learn about art and creativity. Nevertheless, only $1 \%$ supported their children's decision to engage in an art-related career. In Peng's (2004) study of art students' opinions of primary school art classes, the majority of students were uncertain about pursuing art as a career. Similarly, Adejumo (2002) stated that many U.S. students did not consider art to be an important subject in regular school settings. Their parents, teachers and peers believed that outstanding academic achievement was based upon rewarding high grades in reading, writing, and math subjects. In Taiwan, many parents have the same perspective of primary school art as do Americans. Enhancing children's creativity, imagination, and hobby are the most important goals for parents whose children have attended after-school art education settings. One parent said, "I wish art specialists could stir up my child's imagination." Another parent said, "I do not care about my child has learned art skills or not; enriching his creativity is much more important issue." Over $92 \%$ of parents reported that their children made drawings spontaneously at home, and almost $50 \%$ practiced the contents/skills learned in after-school art education settings. More than $75 \%$ of parents did not provide direction or offer suggestions when children made drawings at home. A total of $68.2 \%$ of parents agreed that children engaged more often in art activities at home. The most frequently used art materials at home were markers, crayons, and pencils.

More than $70 \%$ of the children shared their artwork with parents. Over $80 \%$ discussed what they had learned with their parents. When children thought about quitting art programs, most parents advised them and kept communicating with them. A total of $90 \%$ of the parents offered praise and hugs when children did well in art programs; $60 \%$ discussed the children's difficulties with art instruction with the children and sought improvement when they did not perform well in art programs. The majority of parents believed children could attend after-school art education settings at 4 years of age, and also reported that their children had attended art programs at that age. Four-year-old children's drawing at this point has been identified by Lowenfeld (1970) as being at the Pre-Schematic stage. Parents can easily distinguish 4-year-old children's pictorial form from scribbling. As for physical development, children can use fine motor skills to do sophisticate actions at 4 years of age, such as using scissors to cut different shapes (Frost et al., 2001). With regard to cognitive development, children at this age begin to adopt logical thinking at the Preoperational period (Phillips, 1981). The above notions might support parents' decision to invite children to attend after-school art education settings.

Nevertheless, there are also some differences between public and private kindergarten parents' reports. The type of after-school art education settings that children attend differed in this study. Public kindergarteners attended after-school art education settings affiliated with learning centers, while those in private school attended after-school art education settings affiliated with their kindergartens. Most parents reported limiting attendance at public after-school art education settings to 6-10 children; while 10-15 typically attended private settings. The frequency of public kindergarteners' attendance of after-school art education settings was 1-1.5 hours per day; conversely, for private ones it was only 30-60 minutes.

\subsection{Research Question Two: How Does the Availability of Different Types of Kindergartens Influence Parents' Selection of After-School Art Education Settings?}

1) Hypothesis 1: Types of kindergartens would influence parents' selection of after-school art education settings.

Socioeconomic, parents' consideration, and parents' expectation factors affecting kindergarten parents' selection of after-school art education settings differed between public and private kindergartens. This hypothesis was tested using a t-test procedure. The data and results of the analysis related to hypothesis 1 may be found in Table 1. The t-test results for total scores relating to parents' selection of after-school art education settings across two groups of kindergartens appear in Table 1. 
Table 1. T-test for factors affecting parents' selection of after-school art education settings, by type of kindergarten

\begin{tabular}{lllllll}
\hline $\begin{array}{l}\text { Dependent } \\
\text { Variables }\end{array}$ & $\begin{array}{l}\text { Types } \\
\text { Kindergartens }\end{array}$ & of & Mean & $\begin{array}{l}\text { Standard } \\
\text { Deviation }\end{array}$ & $\mathrm{p}$ & t-value \\
\hline Socioeconomic & Public & 236 & 21.00 & 5.12 & $.000^{* * *}$ & -4.106 \\
& Private & 223 & 23.03 & 5.45 & & \\
Parents' & Public & 236 & 21.15 & 2.63 & $.047^{*}$ & \multirow{2}{*}{1.991} \\
Consideration & Private & 223 & 20.64 & 2.81 & & \\
Parents' & Public & 236 & 14.50 & 2.57 & $.007^{* *}$ & -2.709 \\
Expectation & Private & 223 & 15.14 & 2.48 & & \\
\hline
\end{tabular}

$* \mathrm{p}<.05 * * \mathrm{p}<.01 * * * \mathrm{p}<.001$

As Table 1 data show, the effect of the socioeconomic (dependent variable) factor on parents' selection of after-school art education settings differed significantly between public and private kindergarten children. Those parents with children in public kindergartens who attended after-school art education settings had lower scores than those in private kindergartens. As Table 1 data show, parents' consideration (dependent variable) of parents' selection of after-school art education settings also differed significantly between public and private kindergarten children. Those parents with children in public kindergartens who attended after-school art education settings had higher scores than those in private kindergarten. As Table 1 data show, the parents' expectations (dependent variable) of after-school art education settings differed significantly between those with children in public and private kindergartens. Those parents with children in public kindergartens who attended after-school art education settings had lower scores than those in private kindergartens.

\subsection{Research Question Three: How Do Differences in Parents' Backgrounds Influence Their Selection of After-School Art Education Settings?}

1) Hypothesis 2: Parents' selection of after-school art education settings will vary according to mother's age, by examining parents' motivation factor.

It was hypothesized that parents' selection of after-school art education settings would vary according to mother's age. This hypothesis was tested using a One-way ANOVA procedure. The data and results of the analysis related to hypothesis 2 may be found in Table 2. The ANOVA results for total scores on the selection of after-school art education settings across three groups of mothers' age appear in Table 2.

Table 2. One-way ANOVA for selection of after-school art education settings, by mothers' age, three age groups

\begin{tabular}{lllllll}
\hline $\begin{array}{l}\text { Dependent } \\
\text { Variable }\end{array}$ & Source & Sum of Square & D.F. & $\begin{array}{l}\text { Mean } \\
\text { Square }\end{array}$ & F ratio & Scheffé \\
\hline \multirow{2}{*}{$\begin{array}{l}\text { Between } \\
\text { Groups }\end{array}$} & 50.84 & 2 & 25.42 & & \\
Motivation & $\begin{array}{l}\text { Within } \\
\text { Groups }\end{array}$ & 3033.48 & 456 & 6.65 & $3.82^{*}$ & $1>2$ \\
& Total & 3084.33 & 458 & & & \\
\hline
\end{tabular}

$* \mathrm{p}<.05$

( $1=$ Under 35 years old, $2=36-40$ years old, $3=$ Over 40 years old $)$

Table 2 data show that the total scores supported the hypothesis that significantly different scores would be found across the three groups $[\mathrm{F}(2,456)=3.82, \mathrm{p}<.05]$. The Scheffé method was used to identify the specific differences among the groups. The total scores for mothers' age under 35 years were significantly different from those aged 36-40 years old. 
2) Hypothesis 3: Parents' selection of after-school art education settings will vary according to mother's occupation, by examining children's motivation factor.

It was hypothesized that the selection of after-school art education settings for children would differ according to mother's occupation. This hypothesis was tested using a One-way ANOVA procedure. The data and results of the analysis related to hypothesis 3 were found in Table 3. The ANOVA results for the total scores on the selection of after-school art education settings across seven groups of mothers' occupations appear in Table 3 .

Table 3. One-way ANOVA for selection of after-school art education settings, by mothers, seven occupation groups

\begin{tabular}{lllllll}
\hline $\begin{array}{l}\text { Dependent } \\
\text { Variable }\end{array}$ & Source & Sum of Square & D.F. & $\begin{array}{l}\text { Mean } \\
\text { Square }\end{array}$ & F ratio & Scheffé \\
\hline \multirow{2}{*}{$\begin{array}{l}\text { Children, } \\
\text { Motivation }\end{array}$} & $\begin{array}{l}\text { Groups } \\
\text { Within }\end{array}$ & 118.15 & 6 & 19.69 & & \\
& Groups & 1769.99 & 452 & 3.91 & $5.02 * * *$ & $1>7$ \\
& Total & 1888.15 & 458 & & & \\
\hline$* * * \mathrm{p}<.001$ & & & & &
\end{tabular}

$* * * \mathrm{p}<.001$

( $1=$ Government-related, $2=$ Legislators, administrators, business executives \& managers, $3=$ professional-skills, $4=$ Service workers \& shop \& market sales workers, 5= Agricultural, animal husbandry, forestry \& fishing workers, $6=$ Merchants, $7=$ Retirees and housewives $)-($ Executive-Yuan, 2003)

Table 3 data indicate that the total scores supported the hypothesis that significantly different scores would be found across the seven groups $[\mathrm{F}(6,452)=5.02, \mathrm{p}<.001]$. The Scheffé method was used to identify specific differences among the groups. The total scores for mothers' occupations that were government-related were significantly different from those who were retirees and housewives.

3) Hypothesis 4: Parents' selection of after-school art education settings will vary according to fathers' highest level of education, by examining children's motivation factor.

It was hypothesized that the selection of after-school art education settings for their children would vary according to fathers' highest level of education. This hypothesis was tested using a One-way ANOVA procedure. The data and results of the analysis related to hypothesis 4 may be found in Table 4 . The ANOVA results for total scores on the selection of after-school art education settings across six groups of fathers' highest level of education appear in Table 4.

Table 4. One-way ANOVA for selection of after-school art education settings, by fathers' highest level of education

\begin{tabular}{lllllll}
\hline $\begin{array}{l}\text { Dependent } \\
\text { Variable }\end{array}$ & Source & Sum of Square & D.F. & $\begin{array}{l}\text { Mean } \\
\text { Square }\end{array}$ & F ratio & Scheffé \\
\hline & $\begin{array}{l}\text { Between } \\
\text { Groups }\end{array}$ & 64.64 & 4 & 16.16 & & \\
$\begin{array}{l}\text { Children's } \\
\text { Motivation }\end{array}$ & $\begin{array}{l}\text { Within } \\
\text { Groups }\end{array}$ & 1819.12 & 453 & 4.01 & $4.02 * *$ & $3<6$ \\
& $\begin{array}{l}\text { Total } \\
\text { The }\end{array}$ & 1883.77 & 457 & & & \\
\hline
\end{tabular}

$* * \mathrm{p}<.01 * * * \mathrm{p}<.001$

(1=primary school, 2=junior high school, $3=$ senior high school, $4=$ junior college, $5=$ college degree, $6=$ post-graduate degree)

Table 4 data reveal that the total scores supported the hypothesis that significantly different scores would be found across the six groups $[\mathrm{F}(4,453)=4.02, \mathrm{p}<.01]$. The Scheffé method was adopted to identify specific 
differences among the groups. The total scores for fathers' highest level of education that were post-graduate degree holders were significantly different from those who were senior high school degree holders.

4) Hypothesis 5: Parents' selection of after-school art education settings will vary according to mothers' highest level of educational degree, by examining parents' expectation and children's motivation factors.

It was hypothesized that the selection of after-school art education settings for children would vary according to mothers' highest education degree. This hypothesis was tested using a One-way ANOVA procedure. The data and results of the analysis related to hypothesis 5 may be found in Table 5. The ANOVA results for the total scores on the selection of after-school art education settings across the six groups of education degrees among mothers appear in Table 5.

Table 5. One-way ANOVA for selection of after-school art education settings examining parents' expectation and children's motivation factors, by mothers, six groups of highest education degrees

\begin{tabular}{lllllll}
\hline $\begin{array}{l}\text { Dependent } \\
\text { Variables }\end{array}$ & Source & Sum of Square & D.F. & $\begin{array}{l}\text { Mean } \\
\text { Square }\end{array}$ & F ratio & Scheffé \\
\hline & $\begin{array}{l}\text { Between } \\
\text { Groups }\end{array}$ & 133.00 & 5 & 26.60 & & \\
Parents' & Within & 2834.98 & 453 & 6.258 & $4.25^{* *}$ & $3>5$ \\
Expectation & $\begin{array}{l}\text { Groups } \\
\text { Total }\end{array}$ & 2967.99 & 458 & & & \\
& $\begin{array}{l}\text { Between } \\
\text { Groups }\end{array}$ & 92.52 & 5 & 18.50 & & \\
Children's & Within & 1795.62 & 453 & 3.96 & $4.66^{* * *}$ & $3<5$ \\
Motivation & Groups & 1888.15 & 458 & & & \\
& Total & & & &
\end{tabular}

** $\mathrm{p}<.01 * * * \mathrm{p}<.001$

(1=primary school, $2=$ junior high school, $3=$ senior high school, $4=$ junior college, $5=$ college degree, $6=$ post-graduate degree)

Table 5 data show that total scores supported the hypothesis that significantly different scores would be found across the six groups $[\mathrm{F}(5,453)=4.25, \mathrm{p}<.01]$ and $[\mathrm{F}(5,453)=4.66, \mathrm{p}<.001]$. The Scheffé method was used to identify specific differences among the groups. The total scores for mothers' highest education degree/college degree holders differed significantly from those who were senior high school graduates.

\section{Conclusion}

Research on the factors affecting kindergarten parents' selection of after-school art education settings in Taiwan led the researcher to come to the following conclusions:

Art specialists with fine arts degrees are most often found in after-school art education settings. Most parents believed that art specialists have a great impact on children's drawings. The result is the same as Bergonzi and Smith (1996) found that adults' choices and notions vitally influence children's art experiences. The most popular way to teach is to combine teacher-directed and child-directed methods, and the result is the same as Hsiao (2008) studied of teachers' believes and attitudes toward teaching art education in kindergartens. The most frequently used art materials are crayons, markers, and pencils, and the most popular subjects for drawings are animals. The two results are the same as Hsiao (2010) studied of using picture books to improve children's art making and art appreciation ability. Moreover, the same as Lin (2006) study, the majority of children attended after-school art education settings at four years old; hence, they can use fine motor skills and begin to adopt logical thinking.

A total of $85 \%$ of the parents stated that their children have achieved their expectations, which was to enrich creativity, patience, and attention. The same as Fitzhugh (2002) study found that attending after-school art education settings improves youngsters' self-confidence and discipline, awareness of their own creativity, and ability to learn in many subjects. Over $70 \%$ of the children shared their drawings with parents. A total of $68.2 \%$ 
of parents agreed that children do art activities more at home. More than $80 \%$ of the children discussed what they had learned in art classes with their parents.

Type of kindergarten attended by children (public or private) has a significant influence on decision making regarding the selection of after-school art education settings for their children. The result is the same as Pan (2003) study found that children's talent art schools are very prosperous in Taiwan as a result of changes in socioeconomic trends, and parents who earned more money would send their children to private kindergartens that are included talent art classes.

Mother's age \& occupation have a significant influence on decision making regarding the selection of after-school art education settings for their children.

Parents' highest education degree earned has a significant influence on decision making regarding the selection of after-school art education settings for their children. The result is the same as Lin (2006) study found that parents' highest education degrees earned related to type of after-school art education settings selected, and most questionnaires were answered by mothers who obtained college degrees.

Young (2007) claimed that many parents wrongly believed that their children's future could be mapped out by them. Lai (2006) mentioned that in order to cultivate children's creativity, parents should be creative first. Many parents believe that art education is a professional field. Thus, without artistic competence, they believe that they cannot teach their children art. In order to create a better learning environment for after-school art education, the government should provide more art workshops/festivals for parents and instructions that parents may follow at home when engaging in family art activities. To improve teaching quality in after-school art education settings, colleges/universities should provide more art conferences/workshops for art specialists. To correct the commercial purposes of children's art instruction, owners of after-school art education settings should regularly seek the advice of art education professors about the latest findings from research and best practices.

\section{References}

Adejumo, C. O. (2002). Five ways to improve the teaching and understanding of art in the schools. Art Education, 55(5), 7-11. http://dx.doi.org/10.2307/3193952

Baghban, M. (1992). What happens to children's drawing? Paper presented at the Annual Spring Conference of the National Council of Teacher of English, Washington, DC.

Bergonzi, L., \& Smith, J. (1996). Effects of arts education on participation in the arts. Santa Ana, Calif: Seven Locks Press.

Borg, W. R., \& Gall, M. D. (1989). Educational research. New York: Longman.

Chen, D. Z. (1998). Art specialists' handbook-child art. Taipei: National Taiwan Arts Education Center.

Chen, L. T. (1998). Relationships between children's drawings and social contexts. InSEA News, 5(1), 4-7.

Cheng, H. K. (2006). Primary school students' family educational expenditures. Unpublished master's thesis, National Chiayi University, Chiayi.

Chen, Y. H. (2007). A study of private after school art institutions for children on their online marketing package. Unpublished master's thesis, National Dong Hwa University, Hualien.

Danko-McGhee, K., \& Slutsky, R. (2003). Preparing early childhood teachers to use art in the classroom: Inspirations from Reggio Emilia. Art Education, 56(4), 12-23.

Executive-Yuan. (2003). Yearbook of Manpower Survey Statistics, Taiwan Area, Republic of China. Taipei: Executive-Yuan.

Efland, A., Freedman, K., \& Stuhr, P. (1996). Postmodern art education: An approach to curriculum. Reston, VA: National Art Education Association.

Feng, H. X. (2004). A study of learning satisfactions of art-gifted class students at primary schools in Miao-Li county. Unpublished master's thesis, National Hsinchu University of Education, Hsinchu.

Frost, J. L., Wortham, S., \& Reifel, S. (2001). Play and child development. Upper Saddle River, NJ: Merrill Prentice Hall.

Fitzhugh, L. (2002). Filling the gap in after-school arts education. Retrieved March 25, 2012, from the http://education.jhu.edu/newhorizons/strategies/topics/Arts\%20in\%20Education/fitzhugh.htm 
Galbraith, L. (1991). Analyzing an art methods course: Implications for teaching primary student-teachers. $\begin{array}{llll}\text { Journal of Art and Design Education, 10(3), 329-342. } & \end{array}$ http://dx.doi.org/10.1111/j.1476-8070.1991.tb00298.x

Hamblen, K. A. (2003). Local art knowledge: Within children's art work and outside school culture. Visual Arts Research, 29(57), 109-119.

Hanes, J. M., \& Weisman (2000). Observing a child use drawing to find meaning. Art Education, 53(1), 6-11. http://dx.doi.org/10.2307/3193856

Hong, L. (2008). Nurturing children method. Retrieved March 1, 2012, from http://www.parenting.com.tw/article/article. action?id=5020635

Hsiao, C. Y. (2010). Enhancing Children's Artistic and Creative Thinking and Drawing Performance through Appreciating Picture Books Activities. The International Journal of Art \& Design Education, 29(2), 143-152. http://dx.doi.org/10.1111/j.1476-8070.2010.01642.x

Hsiao, C. Y. (2008). The teachers' attitudes toward and beliefs about the role of children's visual art in stimulating their learning and development in Kaohsiung City and County. Journal of National Pingtung University of Education, 31, 33-64.

Lai, S. C. (2006). Creative parents cultivate creative children. Preschool Education, 8, 32-33.

Lasky \& Mukerji. (1980). Art: Basic for young children. Washington, DC: National Association for the Education of Young Children.

Lee, L. H. (2006). After-school arts programs in Taiwan. Retrieved November 10, 2013, from the http://blog.sina.com.tw/joyschool/article.php?pbgid=25721\&entryid $=65457$

Lee, M. W. (2006). Research of the factors of parents' choice for children extra-curriculum activities-instance of public kindergarten in Taipei County. Unpublished master's thesis, National Taipei University of Education, Taipei.

Lin, Y. J. (2006). The survey of factor for parents to choose elementary cram schools. Unpublished master's thesis, Shih Chien University, Taipei.

Liu, F. J. (2001). An analysis on the issue of contemporary art education. Visual Arts, 4, 59-96.

Lowenfeld, V., \& Brittain, V. L. (1970). Creative and mental growth (5th ed.). New York: Macmillan.

Nunnally, J. C. (1978). Psychometric theory (2nd ed.). New York: McGraw-Hill.

Pan, Y. C. (2003). A case study of children art supplementary school in Yung Ho. Unpublished master's thesis, National Taipei University of Education, Taipei.

Phillips, J. L. (1981). Piaget's theory: A primer. San Francisco, CA: W.H. Freeman and Company.

Qian, D. L. (2005). How should parents choose after-school art education settings? ShiYou, 458, 50-54.

Stokrocki, M. (2000). Sociocultural influences on Brazilian children's drawing. Art Education, 53(1), 12-17. http://dx.doi.org/10.2307/3193857

Su, F. Y. (2007). Research on the art specialists' teaching practice in kindergartens. Unpublished master's thesis, National Taiwan Normal University, Taipei.

Tarr, P. (2003). Reflections of the image of the child: Reproducer or creator of culture. Art Education, 56(4), 6-11.

Toku, M. (2001). Cross-cultural analysis of artistic development: Drawing by Japanese and U.S. children. Visual Arts Research, 27(1), 46-59.

Wilson, B. (1992). Postmodernism and the challenge of content: Teaching teachers of art for the twenty-first century. In N. C. Yakel (Ed.), The future: Challenge of change (pp. 99-114). Reston, VA: National Art Education Association.

Young, S. W. (2004). A investigate primary school teacher's perceptions of talented education in Taiwan City. Unpublished master's thesis, National Kaohsiung Normal University, Kaohsiung.

Young, Y. C. (2007). We cannot map out child's future. Preschool Education, 10, 10-12. 


\section{Copyrights}

Copyright for this article is retained by the author(s), with first publication rights granted to the journal.

This is an open-access article distributed under the terms and conditions of the Creative Commons Attribution license (http://creativecommons.org/licenses/by/3.0/). 